\title{
Effect of Calcitonin on Bile Excretion of Calcium and Phosphorus in Sheep
}

Tohru Matsui, Nozomu Kuramitsu, Bunjiro Yao, Hideo Yano and Ryoji Kawashima

Department of Animal Science, Faculty of Agriculture, Kyoto University, Kyoto-shi 606

(Received October 12, 1983)

\begin{abstract}
The bile duct was fitted with a re-entrant cannula in thyroidectomized (TXed) and sham operated (Sham) sheep, respectively. Under pentobarbital anesthesia, porcine calcitonin were infused into TXed wethers at a physiological secretion rate (20 $\mathrm{m} \mathrm{i.} \mathrm{u./kg} \mathrm{body} \mathrm{weight/hr)} \mathrm{and} \mathrm{Sham} \mathrm{ones} \mathrm{were} \mathrm{infused} \mathrm{with} \mathrm{vehicle} \mathrm{alone.} \mathrm{Serum}$ calcium and phosphorus concentrations were decreased and bile inorganic phosphorus excretion were increased by calcitonin infusion. Calcium excretion via bile were decreased in Sham animals infused with vehicle but were not changed in TXed sheep infused with calcitonin. Lipid phosphorus secretion via bile tended to be decreased in both TXed and Sham sheep. The rates of bile calcium and inorganic phosphorus excretion were almost the same as those of urinary excretion. Therefore, it could be considered that calcitonin increased calcium and inorganic phosphorus excretion via bile which were as important as urinary excretion of these minerals.
\end{abstract}

Jpn. J. Zootech. Sci., 55. (3): 191-196, 1984

It is well known that calcitonin has hypocalcemic and hypophosphatemic effects in rats $^{1)}$ and sheep ${ }^{2,8)}$. YAMAGUCHI ${ }^{4}$ suggested that the hypocalcemia induced by calcitonin was partly due to the increased excretion of calcium via bile duct because calcitonin injection ( $80 \mathrm{~m}$ i. u. $/ 100 \mathrm{~g}$ body weight) increased bile calcium excretion in thyroparathyroidectomized rats. However, it might be afraid that the dose of calcitonin injected into rats was pharmacological level because circulating calcitonin in a rat of $150 \mathrm{~g}$ was calculated as approximately $1 \mathrm{~m} \mathrm{i.u.5)}$. Different effects of calcitonin on urinary mineral excretion were observed between rats injected with a large amount of calcitonin and ones injected with a small amount of calcitonin ${ }^{6)}$.

Some workers ${ }^{7.8)}$ indicated that a substantial amount of phosphorus were excreted into the small intestine in sheep. While, the endocrine regulation of phosphorus excretion into the intestine has not been clarified yet.

This experiment was to study the role of calcitonin on calcium and phosphorus excretion via bile in sheep which were infused with calcitonin at a physiological level.

\section{Materials and Methods}

Six adult sheep, weighing about $30 \mathrm{~kg}$, were used. All animals were fed the diet shown in Table 1 at a level of $2 \%$ of body weight daily. Water was available at all time. Three sheep were thyroidectomized (TXed) 3 months before the experiment and the other 3 were sham operated (Sham). In order to supply thyroid hormone, 


\begin{tabular}{|c|c|c|}
\hline \multicolumn{3}{|l|}{ Matsui, } \\
\hline \multicolumn{2}{|c|}{ Ingredient } & $\%$ \\
\hline \multicolumn{2}{|c|}{ Orchardgrass hay } & 59.7 \\
\hline \multicolumn{2}{|c|}{ Ground barley } & 30.0 \\
\hline \multicolumn{2}{|c|}{ Soybean meal } & 9.8 \\
\hline \multicolumn{2}{|c|}{ Sodium chloride } & 0.3 \\
\hline \multicolumn{2}{|c|}{ Calcium carbonate } & 0.2 \\
\hline
\end{tabular}

every TXed sheep was injected intramuscularly with $2.5 \mathrm{mg}$ of L-thyroxine (Nakarai Chemicals Ltd., Kyoto Japan) dissolved in corn oil once a week.

After $24 \mathrm{hr}$ of feeding, the experiment was conducted under pentobarbital anesthesia. The abdomen was opened by a right side incision. The bile duct was fitted with a reentrant cannula of siliconized tube ( $2 \mathrm{~mm}$ of inside diameter) and a ligature was tightened around the bile duct. A siliconized catheter was inserted into the jugular vein to collect blood and to infuse calcitonin or vehicle. TXed sheep were infused with porcine calcitonin (Armor Pharmaceutical Company, Ltd., Eastbourne, England; $80 \mathrm{i} . \mathrm{u} . / \mathrm{mg}$ protein) dissolved in $0.8 \% \mathrm{NaCl}(4 \mathrm{~m} \mathrm{i.u.} / \mathrm{ml})$ at a rate of $20 \mathrm{~m} \mathrm{i.u.} / \mathrm{kg}$ body weight/hr for $5 \mathrm{hr}$. CARE et al.9) indicated that calcitonin secretion rate from the thyroid gland was shown to fluctuate between 5 and $30 \mathrm{~m} \mathrm{i.u.} / \mathrm{kg}$ body weight $/ \mathrm{hr}$ in an ewe when serum calcium concentrations varied between 8 and $12 \mathrm{mg} / 100 \mathrm{ml}$. On the other hand, Sham sheep were infused with $0.8 \% \mathrm{NaCl}$ (vehicle). The bile samples were collected for $10 \mathrm{~min}$ every $1 \mathrm{hr}$ in TXed and Sham sheep.

Calcium concentrations in bile and serum were measured by an atomic absorption spectrophotometry and inorganic phosphorus concentrations were determined by the method of FISKE and SubBarow ${ }^{10}$. Lipid phosphorus in bile was measured by the method of ZILVERSMIT and DAvis ${ }^{11)}$. Statistical differences were evaluated by Student's $t$ test.

\section{Results}

As shown in Table 2, bile secretion rate tended to be reduced in both TXed and Sham sheep and the rate was significantly decreased in Sham animals $4 \mathrm{hr}$ after the beginning of vehicle infusion $(P<0.05)$. However, there was no significant difference in secretion rate of bile between TXed and Sham sheep.

Bile calcium excretion were more in Sham wethers than in TXed ones before infusion $(\mathrm{P}<0.05)$. The significant reduction of bile calcium excretion was found in Sham sheep $(P<0.01)$ but not observed in TXed ones. And bile calcium excretion was more in TXed animals infused with calcitonin than in Sham ones infused with vehicle after $4 \mathrm{hr}$ of the beginning of infusion $(\mathbf{P}<0.05)$.

Bile inorganic phosphorus excretion was increased in TXed animals during the experiment. A significant difference between TXed sheep infused with calcitonin 
Table 2. Effect of calcitonin infusion on rate of bile secretion, bile calcium and phosphorus excretion in sheep

\begin{tabular}{|c|c|c|c|c|c|c|c|}
\hline & & \multirow{2}{*}{$\begin{array}{l}\text { Before } \\
\text { infusion }\end{array}$} & \multicolumn{5}{|c|}{ infusion, $\mathrm{hr}$} \\
\hline & & & 1 & 2 & 3 & 4 & 5 \\
\hline Bile secretion & Sham & $4.02 \pm 0.75$ & $3.53 \pm 1.13$ & $3.27 \pm 1.05$ & $3.00 \pm 1.11$ & 2. $45 \pm 0.81^{*}$ & $2.93 \pm 1.05$ \\
\hline$(\mathrm{ml} / 10 \mathrm{~min})$ & $\mathrm{TX}$ & $3.03 \pm 0.89$ & $2.66 \pm 0.46$ & $2.85 \pm 0.71$ & $2.46 \pm 0.23$ & $2.51 \pm 0.79$ & $2.60 \pm 0.31$ \\
\hline Bile calcium & Sham & $499 \pm 21$ & $367 \pm 89$ & $256 \pm 144$ & $325 \pm 83^{*}$ & $207 \pm 46^{* *}$ & $196 \pm 35^{* *}$ \\
\hline$(\mu \mathrm{g} / 10 \mathrm{~min})$ & $\mathrm{TX}$ & $338 \pm 53^{\mathrm{a}}$ & $306 \pm 25$ & $325 \pm 24$ & $321 \pm 53$ & $355 \pm 22^{\mathrm{a}}$ & $363 \pm 49^{\mathrm{a}}$ \\
\hline $\begin{array}{r}\text { Bile inorganic } \\
\text { phosphorus }\end{array}$ & Sham & $75 \pm 16$ & $73 \pm 14$ & $85 \pm 18$ & $85 \pm 29$ & $83 \pm 14$ & $85 \pm 24$ \\
\hline$(\mu \mathrm{g} / 10 \mathrm{~min})$ & $\mathrm{TX}$ & $68 \pm 9$ & $61 \pm 14$ & $90 \pm 19$ & $101 \pm 21$ & $130 \pm 20^{* a}$ & $120 \pm 19 *$ \\
\hline $\begin{array}{l}\text { Bile lipid } \\
\text { phosphorus }\end{array}$ & Sham & $1.22 \pm 0.07$ & $1.20 \pm 0.28$ & $1.10 \pm 0.16$ & $1.09 \pm 0.15$ & $0.97 \pm 0.33$ & $0.80 \pm 0.19 *$ \\
\hline$(\mathrm{mg} / 10 \mathrm{~min})$ & $\mathrm{TX}$ & $1.28 \pm 0.17$ & $1.11 \pm 0.15$ & $1.10 \pm 0.15$ & 1. $10 \pm 0.35$ & $1.19 \pm 0.67$ & $0.86 \pm 0.04 *$ \\
\hline
\end{tabular}

1) Values were indicated mean $\pm S D$. 2) Sham means sham operated sheep and TX means thyroidecomized sheep. 3) Sham sheep were infused with vehicle and TXed sheep were infused with porcine calcitonin. $*$; Significantly $(P<0.05)$ different from the value before infusion. **; Significantly $(\mathrm{P}<0.01)$ different from the value before infusion. a; Significantly $(\mathrm{P}<0.05)$ different from Sham sheep.

and Sham ones infused with vehicle was found in bile inorganic phosphorus excretion $4 \mathrm{hr}$ after the beginning of infusion.

Bile lipid phosphorus secretion had a trend to be decreased and the reduction was significant in both groups $4 \mathrm{hr}$ after the beginning of infusion $(P<0.05)$. However, the secretion rate of lipid phosphorus were not different between TXed and Sham sheep during the experiment.

As shown in Table 3, serum calcium concentration was slightly higher in TXed animals than in Sham ones before infusion. While the concentrations were signif:cantly reduced in TXed sheep though not changed in Sham ones throughout the

Table 3. Effect of calcitonin infusion on serum calcium and phosphorus concentrations in sheep

\begin{tabular}{|c|c|c|c|c|c|c|c|}
\hline & & \multirow{2}{*}{$\begin{array}{l}\text { Before } \\
\text { infusion }\end{array}$} & \multicolumn{5}{|c|}{ infusion, hr } \\
\hline & & & 1 & 2 & 3 & 4 & 5 \\
\hline $\begin{array}{l}\text { Serum } \\
\text { calcium }\end{array}$ & Sham & $8.01 \pm 0.55$ & $7.87 \pm 0.58$ & $8.38 \pm 0.48$ & $8.13 \pm 0.61$ & $7.87 \pm 0.44$ & $7.95 \pm 0.36$ \\
\hline$(\mathrm{mg} / \mathrm{l} / \mathrm{m} l)$ & $\mathrm{TX}$ & $9.03 \pm 0.45$ & $8.16 \pm 0.55$ & $7.51 \pm 0.54^{*}$ & $7.07 \pm 0.51 *$ & $6.92 \pm 0.37 * *$ & $6.19 \pm 0.12^{* * b}$ \\
\hline $\begin{array}{l}\text { Serum } \\
\text { phosporus }\end{array}$ & Sham & $5.01 \pm 0.38$ & $5.27 \pm 0.56$ & $5.82 \pm 0.67$ & $5.75 \pm 0.65$ & $6.15 \pm 0.50$ & $6.07 \pm 0.64$ \\
\hline $\begin{array}{l}(\mathrm{mg} / \\
100 \mathrm{~m} l)\end{array}$ & $\mathrm{TX}$ & $4.97 \pm 0.25$ & $4.19 \pm 0.53$ & $4.10 \pm 0.58^{\mathrm{a}}$ & $3.87 \pm 0.41^{*^{a}}$ & $3.81 \pm 0.35^{* b}$ & $3.85 \pm 0.38^{* b}$ \\
\hline
\end{tabular}

1) Values were indicated means \pm SD. 2) Sham means sham operated sheep and TX means thyroidectomized sheep. 3) Sham sheep were infused with vehicle and TXed sheep were infused with porcine calcitonin. *; Significantly. $(\mathrm{P}<0.05)$ different from the value before infusion. ${ }^{* *}$; Significantly $(\mathrm{P}<0.01)$ different from the value before infusion. "; Significantly $(P<0.05)$ different from Sham sheep. $\quad$; Significantly $(P<0.01)$ different from Sham sheep. 
experiment. At the 5 th $\mathrm{hr}$ of infusion, serum calcium were significantly lower in TXed wethers than in Sham ones $(P<0.01)$.

Serum inorganic phosphorus concentrations appeared to be increased in Sham sheep, on the contrary, serum inorganic phosphorus were substantially decreased by calcitonin infusion in TXed sheep. The differences of serum inorganic phosphorus between TXed and Sham animals were significant after $2 \mathrm{hr}$ of the beginning of infusion $(P<0.05)$.

\section{Discussion}

Serum calcium and inorganic phosphorus concentrations in TXed sheep were decreased by calcitonin infusion which was thought to be as much as physiological secretion rate in a normal ewe $\mathrm{e}^{\mathrm{g}}$. Therefore, the results showed that calcitonin reduced serum calcium and inorganic phosphorus even though the hormone was infused into wethers at a physiological secretion rate.

The secretion rate of bile was not different between TXed animals and Sham ones. HUFNer et al. ${ }^{12)}$ indicated that calcitonin reduced the gallbladder contraction and decreased bile secretion rate in man. However, the results from the experiment using sheep could not support their report.

Although there was no reduction in bile calcium excretion in TXed wethers infused with calcitonin, bile calcium excretion were decreased in Sham ones. It could be considerable that calcitonin enhanced calcium excretion via bile in sheep. The rate of bile calcium excretion was $196 \mu \mathrm{g} / 10 \mathrm{~min}$ in Sham sheep and was $363 \mu \mathrm{g} / 10 \mathrm{~min}$ in TXed ones $5 \mathrm{hr}$ after the beginning of infusion. Recently, YamaGuCHI ${ }^{4}$ also reported that calcitonin injection increased bile calcium excretion in thyroparathyroidectomized rats. BARLET ${ }^{3)}$ indicated that urinary calcium excretion was $27 \mathrm{mg} /$ day, that is, 188 $\mu \mathrm{g} / 10 \mathrm{~min}$ in sheep infused with vehilce and was $54 \mathrm{mg} /$ day, that is, $375 \mu \mathrm{g} / 10 \mathrm{~min}$ in sheep infused with calcitonin. It could be considerable that both of urine and bile excretion induced the reduction of serum calcium concentrations. Therefore the role of calcitonin on bile calcium excretion would be as important as that on urinary calcium excretion in sheep. It was not clear why bile calcium excretion was reduced in Sham sheep. But it may be possible that the decrease of bile calcium excretion rate is owing to the reduction of bile secretion in Sham sheep infused with vehicle.

The elevation of bile inorganic phosphorus excretion was more in TXed animals infused with calcitonin than in Sham ones infused with vehicle. The results indicated that calcitonin increased inorganic phosphorus excretion via bile. It was reported by TALMAGE et $a l^{13)}$ that calcitonin decreased plasma phosphate concentrations by moving this ion out of extra cellular fluid such as blood plasma. And MEYER and MEYER $^{6}$ ) reported that liver phosphate was increased by calcitonin injection in thyroparathyroidectomized rats. It might be hypothesized that inorganic phosphorus were exuded from hepatic cell to bile by means of the increase of inorganic phosphorus concentrations in hepatic cell when calcitonin was administrated.

BARLET $^{3)}$ indicated that inorganic phosphorus excretion in urine was $12 \mathrm{mg} / \mathrm{day}$, 
that is, $83 \mu \mathrm{g} / 10 \mathrm{~min}$ in sheep infused with vehicle and was $38 \mathrm{mg} /$ day, that is, 264 $\mu \mathrm{g} / 10 \mathrm{~min}$ in sheep intused with calcitonin. It was shown in this experiment that bile inorganic phosphorus excretion was reached $85 \mu \mathrm{g} / 10 \mathrm{~min}$ in Sham sheep infused with vehicle and $120 \mu \mathrm{g} / 10 \mathrm{~min}$ in TXed ones infused with calcitonin $5 \mathrm{hr}$ after the beginning of infusion. It could be considered that calcitonin acted on the liver as same as the kidney in stand point of calcium and phosphorus excretion.

Bile lipid phosphorus secretion had a trend to decrease in both TXed and Sham wethers during the experiment. The secretion of lipid phosphorus was about 10 fold more than the excretion of bile inorganic phosphorus. If the substantial amount of phospholipid which secreted into the intestine had been lost via feces, sheep should become phosphorus deficiency. However, Adams and Hearh ${ }^{15)}$ suggested that the large amount of phospholipid which entered the duodenum via bile might facilitate the uptake of fat into the cells of the intestinal mucosa. It would be natural to consider that most of all phospholipid secreted into the intestine was reabsorbed in sheep because sheep did not become phosphorus deficiency notwithstanding the large amount of lipid posphorus secretion via bile.

\section{Acknowledgements}

This study was supported by Nissin Seifun Foundation.

\section{References}

1) Hirsch, P. F., E. D. Voelkel and P. L. Munson, Science, 146: 412-413. 1964.

2) Matsui, T., N. Kuramitsu, H. Yano and R. Kawashima, Endocrinol. Japon., 30: 485-490. 1983.

3) Barlet, J. P., J. Endocrinol., 55: 153-161. 1972.

4) Yamaguchi, M., Endocrinol. Japon., 25: 533-537. 1978.

5) Olson, E. B. Jr., H.F. Deluca and J. T. Potts, Jk., Endocrinology, 90: 151-157. 1972.

6) Kimura, T. and E. Ogata, Hormone to Rinshou, 21: 1209-1215. 1973.

7) Church, D. C., J.P. Fontenot, G. E. Smith and A. T. Ralston, in Digestive physiology and nutrition of ruminant. volume 2. 436. O. S. U. Books. Oregon. 1971.

8) Young, V. R., G. P. Lofgreen and J. R. Luick, Br. J. Nutr., 20: 795-805. 1966.

9) Care, A. D., C. W. Cooper, T. Duncan and H. Orimo, in Parathyroid hormone and thyrocalcitonin. (Talnage, R. V. and L. F. Belanger eds.) 417-427. Excerpta Medica Foundation. Amsterdam. 1968.

10) Fiske, C. H. and Y. Subbarow, J. Biol. Chem., 66: 375-400. 1925.

11) Zilversmit, D. B. and A. D. Davis, J. Lab. Clin. Med., 35: 155-160. 1950.

12) Hufner, M., R. D. Hesch, H. Schmidt, M. Hasenjager, K. Winkler, W. Creutzfeldt and K. Paschen, Acta Endocrinologia, 159: 65. 1972.

13) Talmage, R. V., J. J. Anderson and C. W. Cooper, Endocrinology 90: 1185-1191. 1972

14) Adams, E. P. and T. J. Heath, Biochem. Biophys. Acta. 70: 688-690. 1963. 


\title{
めん羊においてカルシトニン投与が胆汁経由の カルシウムとリン排泄に及ぽす影響
}

\author{
松井 徹・會光 望・八尾文二郎 \\ 矢野秀雄・川島良治 \\ 京都大学農学部，京都市 606
}

めん羊を用いて，カルシトニンが胆汁経由のカルシウ ムとリン排淤に及ぼす影響を明らかにするために本試験 を行なった。甲状腺摘除（TX）または擬似手術（Sham） を行なった。めん羊の胆管に，カニューレを装着した。 ペントバルビタール麻酔下で, ブタカルシトニンを 0.8 \%食塩水に溶加し, 生理学的分泌速度 $(20 \mathrm{~m}$ i. u. $/ \mathrm{kg}$ 体 重/時間) で, TX 動物の頸静脈に注入し，また，Sham めん羊には $0.8 \%$ 食塩水のみを注入した.

カルシトニン投与により，TX めん羊では血清中カル シウムおよびリン濃度は低下し, 胆汁経由の無機りン排 泄速度は增加した．Sham めん羊では，血清中カルシウ ム,リン濃度および胆汁経由の無機りン排泄速度は有意
に变化しなかったが，胆汁経由のカルシゥム排泄速度は 減少した. 一方,カルシトニン投与により， TX めん羊 では，胆汁経由のカルシウム排泄には変化が生じなが た. 胆汁経由の脂質態リン排泄速度は，TX めん羊， Sham めん羊のいずれにおいても低下した，胆汁経由の 無機りン，カルシウム排泄速度は，報告されている尿経 由の排泄速度とほぼ同程度であった。

これらの結果から，カルシトニンは，胆汁释由のカル シウムおよび無機リン排泄を増加させること，また，こ れらの排汫は尿中へのカルンウムお゙ざ無機りン排泄と 同程度に重要であることが示唆された。

日畜会報，55(3)：191-196，1984 